\title{
Mechanical Behavior of Sustainable Hybrid-Synthetic Fiber Reinforced Cellular Light Weight Concrete for Structural Applications of Masonry
}

\author{
Mohammad Abdur Rasheed ${ }^{1)}$, S. Suriya Prakash' ${ }^{2 *}$ \\ ${ }^{1)}$ Graduate Student, Email: ce13m1024@iith.ac.in \\ 2)*Assistant Professor and Corresponding Author, Email: suriyap@iith.ac.in \\ Department of Civil Engineering \\ Indian Institute of Technology, Hyderabad, India.
}

\section{Abstract}

Cellular light weight concrete (CLC) masonry has gained tremendous popularity in recent decades owing to its sustainability, density, low thermal conductivity and use of less mortar joints. The objective of this study is to develop a high performance fiber reinforced cellular concrete to provide a better alternative than aerated autoclaved concrete blocks for structural applications of masonry. Use of micro-fibers (Fibrillated) enhances pre-cracking behavior of masonry by arresting cracks at micro-scale, while Macro (structural) fibers induce ductile behavior in post-peak region by arresting the crack propagation soon after the crack initiation. In particular, the mechanical behavior of CLC cylinders under pure compression and CLC blocks under flexure with and without polyolefin structural fiber reinforcement as well as hybrid fiber reinforcement is investigated. Test results indicate that the addition of structural fibers improved the compressive strength upto $66.8 \%$ for $0.55 \%$ volume fraction. Post-peak ductility improved upto a factor of nine in case of compression for $0.55 \%$ volume fraction. Similarly, it resulted in $15.31 \%$ increase of post-peak flexural ductility by a hybrid addition of $0.44 \%$ and $0.02 \%$ volume fraction of macro and micro fibers respectively. Hybrid fiber reinforcement enhanced the peak strength and ductility which indicated better crack bridging both at micro and macro levels.

Keywords: Cellular Concrete; Compression; Flexure; Hybrid-synthetic Fibers; Stress-strain curves; Load-displacement Curves; Fiber Dosage; masonry 


\section{INTRODUCTION}

Cellular light weight concrete (CLC) is produced by mixing cement, fly-ash, foam and water in required proportions using ready mix plant or ordinary concrete mixer. The foam is pumped through specialized equipment that adds fixed volume of air voids at constant pressure [1]. Millions of isolated tiny air bubbles with protein-hydrolyzed covering are created. The foam formation does not involve any gas releasing chemical reaction, and therefore it does not expand and maintains its density [2]. Environmental impact assessment studies by LEED (Leadership in Energy and Environmental Design, a green building certification authority in USA) has found that CLC technology is sustainable and can help in producing green building materials [3]. This is due to its low direct $\mathrm{CO}_{2}$ emission and usage of waste byproducts (flyash) from industries in the production process [4-5]. Flyash which itself is by-product of industries, shows a positive effect on compressive strength when added in optimum amount [6]. Moreover, no emission of pollutants during manufacturing makes it a viable alternative to red clay burnt bricks. Burnt clay bricks uses top soil as raw material [7] and require approximately 50 tons of firewood for 1,00,000 bricks (direct thermal requirement). In addition, CLC offer strength, dead load reduction and thermal insulation [8]. Due to lack of reinforcement, CLC has limited ability to dissipate energy and this raises concerns for its seismic applications. On the other hand, Fiber Reinforced Concrete (FRC) has greater energy absorbing ability called ductility or inelastic deformation capacity [9-10]. Addition of fibers in CLC precast units will be advantageous as it possess the comfort of light weight concrete and improved mechanical properties of FRC.

A large percentage of the building stocks in India and around the world comprise of nonengineered unreinforced masonry (URM). The performance of these buildings in the past has shown that these masonry buildings are highly vulnerable to failure under seismic loads. In 
particular, URM exhibits brittle failure modes under seismic loading [11] and are prone to complete collapse leading to loss of life and property. The most widespread collapsing mechanisms commonly encountered in URM buildings under seismic loading involve both the out-of-plane and in-plane failure modes [12]. As the unreinforced masonry walls contribute to the lateral seismic resistance of the building, the first possible failure mode is inplane shear failure. The other type of failure is represented by the out-of-plane flexural failure due to the orthogonal inertial forces induced by the earthquake. Excessive out of plane bending also reduces the vertical load carrying capacity of URM walls and thereby leading to failure under in plane conditions. It is essential to develop low-cost brick masonry systems with improved tensile and shear strength to minimize the loss of life and property during earthquake events. It is worth mentioning that bricks of low strength (varying from 4 to 10 MPa) are commonly used for masonry load bearing and infill wall construction in the developing countries. Therefore, the purpose of this study is to explore the development of sustainable low cost fiber reinforced blocks for structural applications of masonry that can result in better seismic performance. In particular, the focus is on developing a highperformance fiber reinforced cellular concrete without the high-pressure steam curing process as an alternative to Aerated Autoclaved Concrete (AAC) blocks.

\section{LITERATURE REVIEW}

The light-weight concrete can be broadly categorized into three groups: (i) No-fines concrete, (ii) Lightweight aggregate concrete (iii) Aerated concrete. The aerated/foam concrete is the basis of CLC technology. CLC can be classified based on method of pore formation such as (i) Air-entraining method (gas concrete) (ii) Foaming method (foamed concrete) (iii) Combined pore forming method. The classification is also possible based on 
method of curing as (i) Non autoclaved aerated concrete and (ii) Autoclaved aerated concrete. Table 1 reports a summary of previous research that has been done in the past with respect to aerated concrete.

Rudolph and Valor [13] carried out tests on cellular concrete and suggested that flexure strength of CLC was $1 / 3$ to $1 / 5$ of compressive strength. Sengupta [14] used flyash as partial replacement of binder and concluded that, utilizing flyash to produce aerated concrete is an economically attractive proposition, which will help in mitigating the environmental damage eaused by flyash. Panesar [15] has recently investigated the effect of synthetic and protein foaming agents on cellular concrete properties. The author reported that cellular concrete has good potential to be used for lightweight structural applications owing to its evolution of mechanical properties, transport properties and thermal resistance. Esmaily and Nuranian [16] have developed non-autoclaved high strength cellular concrete from alkali-activated slag. The authors reported that substitution of usual cementitious materials by alkali activated slag can eliminate autoclave curing stage and convert it to steam curing. Yang and Lee [17] has recently developed high performance aearated concrete to replace AAC block. The authors tested 16 concrete mixes for various test parameters including the foaming volume rate of the preformed foam, water-to-binder ratio, and unit binder content. They concluded that the developed high-performance aerated concrete had considerable potential for practical applications. Previous work on CLC by Laurent- [18] suggest that thermal conductivity depends on density, moisture content and ingredients of the material. Finer the pores better is the thermal insulation. Leitch [19] observed that the sound insulation, like thermal and fire insulation, is affected by the closed porous structure. The author concluded that due to the porous structure, CLC has good acoustic insulation. 
The usage of Polypropylene fibers has gained more prominence in the recent years for reinforcing cementitious materials [20-22]. Previous investigations have revealed that addition of fiber has improved post-cracking behavior of concrete, showing ductile behavior 103 by arresting the crack propagation soon after the crack initiation [20-22].-However, such studies in CLC masenry is searce and needs attention to better understand the fracture behavior under flexure and shear. Tests carried out by Ronald and Carol [23] indicate the ability of micro-fiber reinforcement to transform the basic material character of cellular concrete from brittle to ductile elasto-plastic behavior. The authors found that the performance of the fiber reinforced CLC was better compared to the control ones.

Mechanical behavior of normal weight concrete with synthetic fibers of $40 \mathrm{~mm}$ length was explored by Deng and Li [24]. The authors observed that hybrid fibers can significantly improve the toughness, flexural impact performance and fracture properties of concrete compared to that of single fiber addition. Laukaitis et al. [25] investigated the influence of micro fibrous additives (carbon, poly-propylene, basalt, kaoline) on properties of aerated autoclaved concrete forming mixtures and strength characteristics of the developed products. The authors found that fibrous additives, both non-hydrophilized and hydrophilized, 117 increased the compression- and flexural strengths of aerated autoclaved concretes. It is worth mentioning that addition of synthetic fibers with low melting temperature in the production of AAC blocks will result in melting and decomposition of the synthetic fibers due to application of high temperature. Therefore, the efficiency of fibers may be compromised in the production of AAC blocks. 
Table 1. Overview of salient literature pertaining to the structure and properties of aerated concrete C-cement, L-lime, S-Sand, F-Flyash, Q-quartz, W-slate waste, mc-moist curing, ac-autoclave curing.

\begin{tabular}{|c|c|c|c|c|c|c|c|c|c|c|c|c|c|c|}
\hline \multirow{3}{*}{ Reference } & \multicolumn{8}{|c|}{ Parameter studied } & & & & & & \multirow{3}{*}{$\begin{array}{l}\text { Salient features of the } \\
\text { study }\end{array}$} \\
\hline & \multicolumn{2}{|c|}{ Ingredients } & \multicolumn{2}{|c|}{ Method of aeration } & \multicolumn{2}{|c|}{ Curing method } & \multicolumn{2}{|c|}{ properties } & & & & $\begin{array}{c}\text { Micro- } \\
\text { structure }\end{array}$ & $\begin{array}{l}\text { Chemical } \\
\text { composition }\end{array}$ & \\
\hline & binder & filler & gas & foam & $\mathrm{Mc}$ & $\mathrm{ac}$ & strength & density & shrinkage & porosity & $\begin{array}{l}\text { Functional } \\
\text { proportion }\end{array}$ & & & \\
\hline Valore 1954 [13] & $\mathrm{C}, \mathrm{L}$ & $S$ & yes & yes & yes & yes & yes & yes & yes & & yes & & & Review on properties \\
\hline Hoff 1972 [27] & $\mathrm{C}$ & S & yes & & & yes & yes & & & yes & & & & $\begin{array}{l}\text { strength porosity } \\
\text { relation }\end{array}$ \\
\hline Mitsuda 1977 [28] & $\mathrm{C}$ & $S$ & yes & & & yes & & & & & & & yes & Anomalous tobermorite \\
\hline Alexanderson 1979 [29] & $\mathrm{C}$ & S & yes & & & yes & & & & yes & & & & $\begin{array}{c}\text { Structure-Mechanical } \\
\text { properties }\end{array}$ \\
\hline Watson 1980 [30] & $\mathrm{C}, \mathrm{W}$ & S & yes & & & yes & yes & yes & & yes & yes & & & Use of slate waste \\
\hline Leitch FN 1980 [49] & $\mathrm{C}$ & $\mathrm{S}$ & yes & & & yes & & & & & yes & & & $\begin{array}{l}\text { Fire resistance and } \\
\text { acoustics }\end{array}$ \\
\hline Tada , and Nakuno 1983 [31] & $\mathrm{C}$ & $S$ & yes & yes & yes & & & & & & & & & $\begin{array}{c}\text { Micro and macro } \\
\text { capillaries }\end{array}$ \\
\hline Tam 1987 [32] & $\mathrm{C}$ & $\mathrm{S}$ & & yes & yes & & yes & & & & & & & Strength-composition \\
\hline Georgiades 1991 [33] & $\mathrm{C}$ & $\mathrm{S}$ & yes & & & yes & & & yes & & & & & Micropore-shrinkage \\
\hline $\begin{array}{c}\text { Sengupta } 1992 \text { (Sengupta J } \\
1992 \text { ) } \\
\end{array}$ & $\mathrm{C}, \mathrm{L}$ & F & yes & & yes & yes & yes & yes & & & & & & Flyash cellular concrete \\
\hline Laurent 1995 [34] & $\mathrm{C}$ & $\mathrm{S}$ & yes & & & yes & & & & & yes & & & Thermal conductivity \\
\hline Odler and Robler 1995 [35] & $\mathrm{C}$ & Q & yes & & & yes & yes & & & & & & & $\begin{array}{c}\text { Particle size on } \\
\text { properties }\end{array}$ \\
\hline Haneck et,al. 1997 [36] & $\mathrm{C}$ & $\mathrm{S}$ & yes & & & yes & yes & yes & & & & & yes & Carbonation \\
\hline Durack 1998 [37] & $\mathrm{C}$ & $\mathrm{F}$ & & yes & yes & & yes & & & yes & & & & Strength-gel space ratio \\
\hline $\begin{array}{c}\text { Kearsley and Wainwright } 2002 \\
{[38]}\end{array}$ & $\mathrm{C}$ & $\mathrm{F}$ & & yes & yes & & yes & & & yes & yes & & & $\begin{array}{l}\text { Porosity compressive } \\
\text { strength relation }\end{array}$ \\
\hline Jones and Macathy 2005 [39] & $\mathrm{C}$ & $S$ & & yes & & & yes & & yes & & & & & $\begin{array}{c}\text { Potential of CLC as } \\
\text { structural material }\end{array}$ \\
\hline $\begin{array}{c}\text { Ramamurthy and Nambiar } 2007 \\
{[40]}\end{array}$ & $\mathrm{C}$ & $\mathrm{F}$ & & yes & yes & & yes & yes & & yes & & yes & & $\begin{array}{c}\text { Air-void } \\
\text { characterization } \\
\end{array}$ \\
\hline Esmaily and Nuranian 2012[23] & $\mathrm{C}$ & & yes & yes & & & yes & yes & & & & & & $\begin{array}{c}\text { Alkali slag cellular } \\
\text { concrete }\end{array}$ \\
\hline Ameer et.al. 2015 [41] & $\mathrm{C}$ & S & & yes & yes & & & & & yes & yes & yes & yes & Pore size distribution \\
\hline
\end{tabular}


122

123

124

\section{RESEARCH MOTIVATION AND OBJECTIVES OF STUDY}

Critical review of literature indicates that only a handful of studies have focused on fiber reinforced CLC for structural applications of masonry. Improved compression, shear and tensile resistance can be expected with hybrid addition of structural/macro fibers along with micro-fibers for superior crack resistance at both micro and macro levels. It is worth mentioning that addition of synthetic fibers in the production of AAC blocks may result in melting of the synthetic fibers due to application of high temperature. Therefore, it is essential to develop a high-performance fiber reinforced cellular concrete without the highpressure steam curing process to replace currently used AAC blocks. Review of previous literature indicates there is very limited information on the mechanical behavior of CLC masonry (foam concrete with density of $800-900 \mathrm{~kg} / \mathrm{m}^{3}$ ). Moreover, the influence of fibers in improving the toughness and strength of CLC has not been explored well yet. The present work tries to fill in these knowledge gaps in this important area. The purpose of this study is to explore the development of sustainable low cost fiber reinforced blocks for structural applications of masonry that can result in better seismic performance. The specific objectives of the work is (i) to develop low cost fiber reinforced CLC blocks for masonry applications and (ii) to investigate their mechanical properties under compression and flexure with different fiber dosages and (iii) to understand the effectiveness of fibers on toughness index of the developed CLC blocks.

\section{EXPERIMENTAL PROGRAM}

\subsection{Materials}

The materials used for the non-fibrous control CLC mixture consisted of 53 grade Ordinary Portland Cement (OPC), fFlyash from NTPC (National Thermal Power Corporation), potable 
water and a commercially available foaming agent. A commercially available foaming agent

147 with a product name "Sunlite Foam SF-30 SPL" is used in this study. The foaming agent

(by volume), and then aerated to a density of $70 \mathrm{~kg} / \mathrm{m}^{3}$. The mix proportion of flyash: cement:

water: foam was 833: 277: 277: $1.4 \mathrm{~kg} / \mathrm{m}^{3}$. Water-binder ratio is kept constant at 0.38 ,

considering the fly-ash also acts as binder. The addition of fibers in the mix by volume proportion is not greater than $0.55 \%$ in case of highest dosage of fiber i.e, $5 \mathrm{~kg} / \mathrm{m}^{3}$. For a proportion. For instance, the addition of fiber for $0.55 \%$ volume fraction is $5 \mathrm{~kg}$ per cubic meter of concrete. The volume fraction of fiber is determined by the following equation: $\frac{V o l_{\text {fiber }}}{V o l_{\text {fiber }}+V o l_{\text {mix }}}$.

157 The volume fraction of fiber $\left(\operatorname{Vol}_{\text {fiber }}\right)$ is very less compared to the volume of mix $\left(\operatorname{Vol}_{\text {mix }}\right)$. Therefore, the impact of addition of fiber in the mix proportion volume was found to be negligible. Fibers used in this study are coarse bi-component macrofiber and fibrillated fibers as shown in the Figs. $1 \& 2$. The physical properties of fibers [26] are mentioned in Table 2.

161 A batch of specimen with different volume fraction of macro-fibers such as $0 \%, 0.22 \%$,
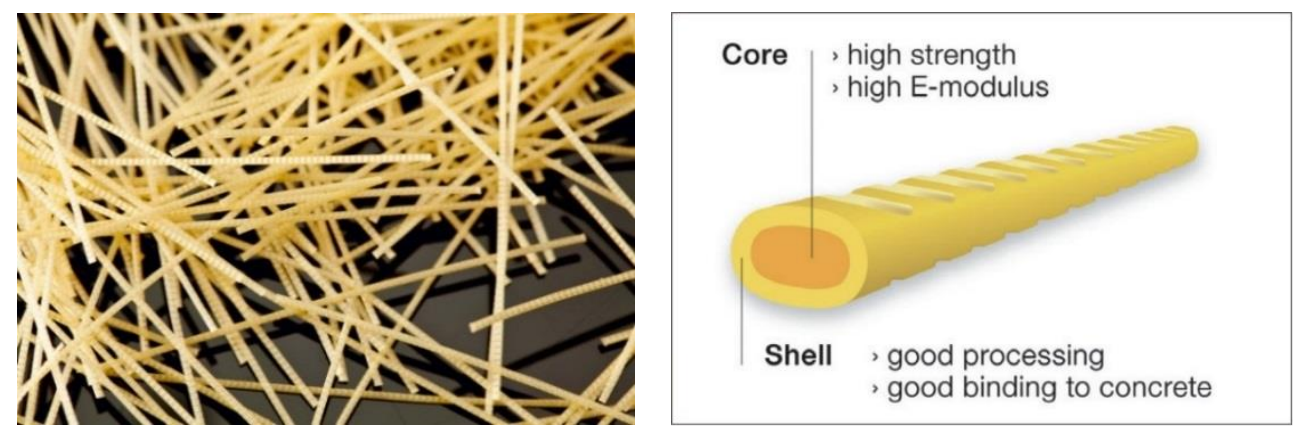

Fig. 1 Poly-Olefin Macrofiber 

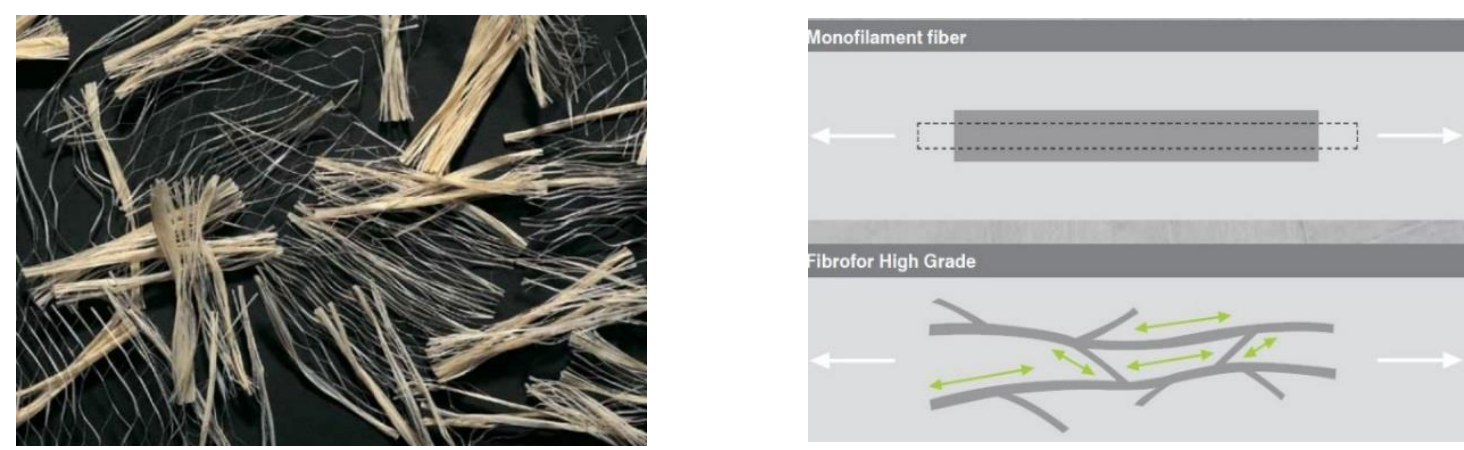

Fig. 2 Poly-Olefin Fibrillated Fiber

Table 2 Physical Properties of Poly-Olefin Fiber

\begin{tabular}{|c|c|c|}
\hline & Macro Fiber & Fibrillated Fiber \\
\hline Specification & Bi-component fiber & Interlinked fiber \\
\hline Material & Poly olefin & Poly olefin \\
\hline Form & Structural fiber & Fibrillated fiber \\
\hline Specific Gravity & 0.91 & 0.91 \\
\hline Length & $50 \mathrm{~mm}$ & $19 \mathrm{~mm}$ \\
\hline Tensile Strength & $618 \mathrm{~N} / \mathrm{mm}^{2}$ & $400 \mathrm{~N} / \mathrm{mm}^{2}$ \\
\hline Modulus of Elasticity & $10 \mathrm{GPa}$ & $4.9 \mathrm{GPa}$ \\
\hline Diameter & $0.5 \mathrm{~mm}$ & $0.08 \mathrm{~mm}$ \\
\hline Melting Temperature & $180^{\circ} \mathrm{C}$ & $180^{\circ} \mathrm{C}$ \\
\hline Decomposition Temperature & $360^{\circ} \mathrm{C}$ & $360^{\circ} \mathrm{C}$ \\
\hline
\end{tabular}

\subsection{Mixing and Curing}

The dry ingredients i.e., cement and flyash were fed into the mixer and thoroughly mixed to ensure even distribution of cement as shown in Fig. 3a. Thereafter, water was added and the mixing process continued. Foam was added at $35 \mathrm{gm} / \mathrm{sec}$ for 40 seconds to the slurry of cement, flyash and water in the batch mixer as per the code specification [41]. The flyash content in CLC mix has been derived from earlier works on CLC containing pozzolan materials [42]. After an additional mixing for three minutes along with fibers to get uniform consistency, the slurry form CLC was poured into rectangular moulds of dimension $600 \mathrm{~mm}$ x $150 \mathrm{~mm}$ x $200 \mathrm{~mm}$ for making blocks (Fig. 3c). 


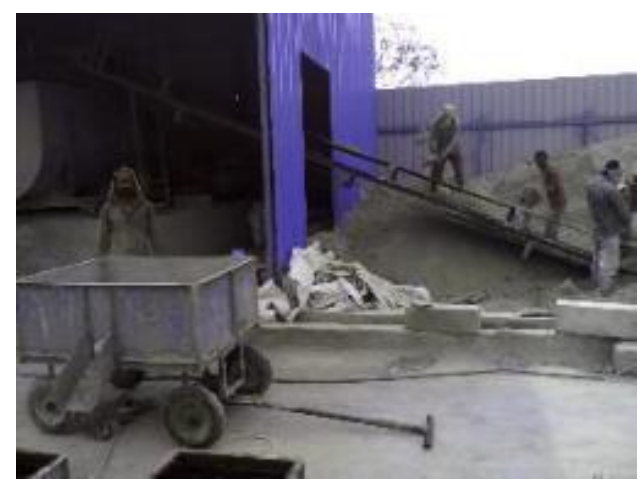

(a) Feeding

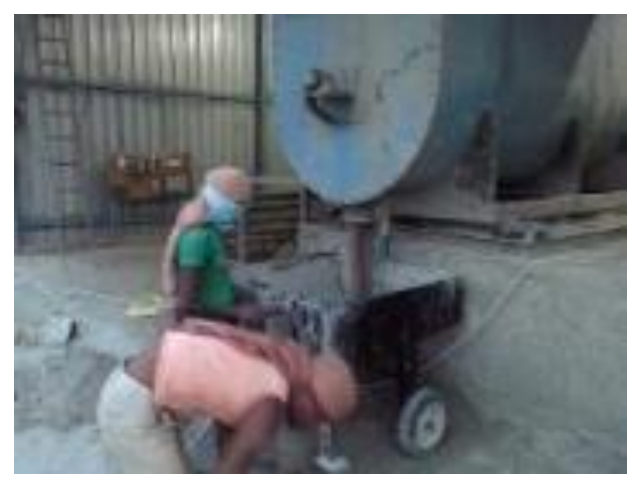

(c) Extracting

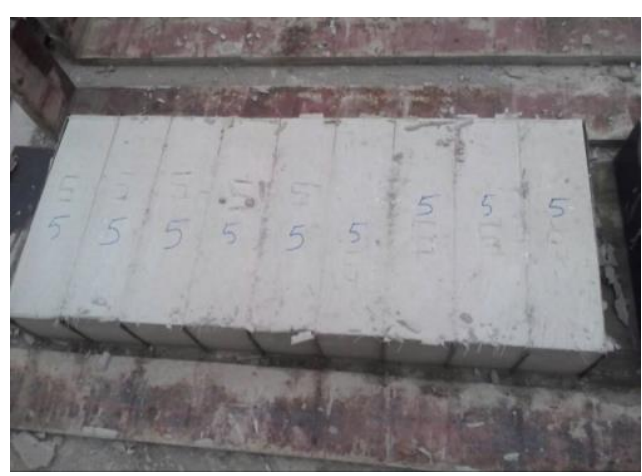

(e) Demoulding

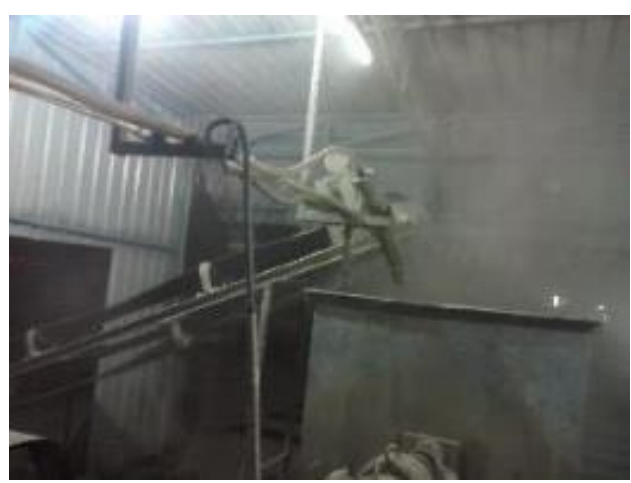

(b) Mixing

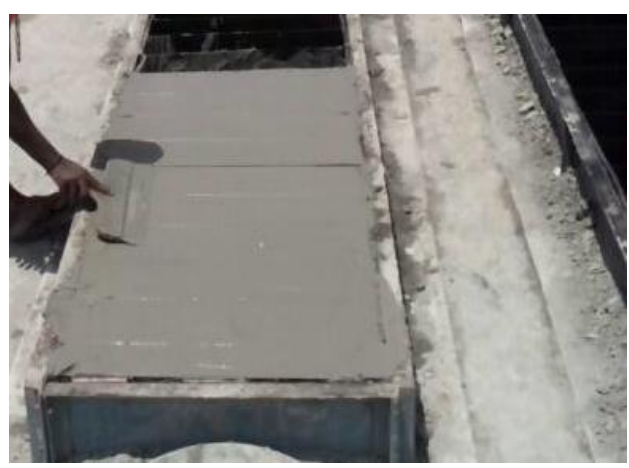

(c) Pouring in moulds

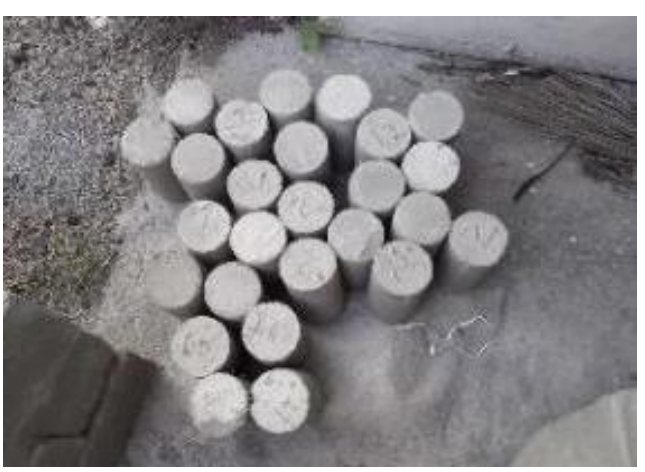

(e) Curing of cylinders

Fig. 3 -Mixing, Placing and Curing of CLC cylinders and blocks.

177 Cylinder specimens with $100 \mathrm{~mm}$ diameter and height of $200 \mathrm{~mm}$ were cast to understand the compression behavior. CLC mix used in this study does not have any aggregates. The mix contained only cement, fly-ash, foaming agent, water and different dosages of fibers. Therefore, the mix remained in liquid state even after addition of fibers. Patty tests showed 
the spread was more than $500 \mathrm{~mm}$ even at addition of high fiber dosages of $0.55 \%$.

182

183

184

Specimens were demoulded 24 hours after curing per IS-456 2000 [43]. Testing was carried out after water curing the cylinders and blocks for 28 days. Density of light weight concrete is kept as $900 \mathrm{~kg} / \mathrm{m}^{3}$. Addition of fibers did not have a significant impact on the density of CLC due its density $\left(910 \mathrm{~kg} / \mathrm{m}^{3}\right)$ being similar to that of fibers. Total void ratio of foamed concrete is 0.35 . Preliminary results showed that water absorption of CLC blocks was about 20 to $25 \%$. High water absorption could be a concern for external applications. However, economical solution of bonding vitrified tiles on external surface can eliminate the water percolation in external applications.

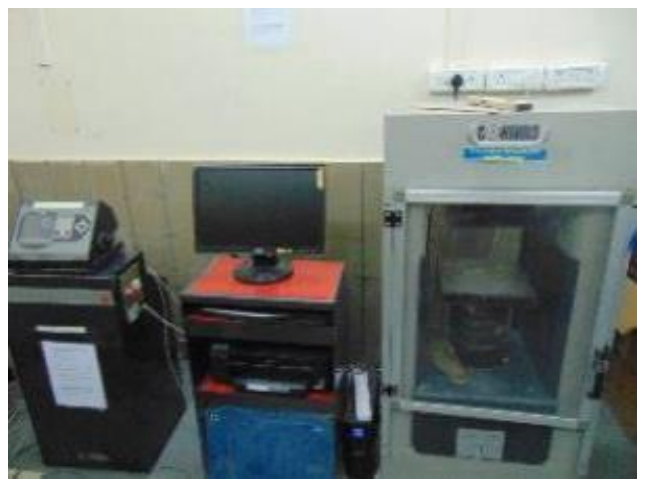

(a) Controls Compression Testing Equipment

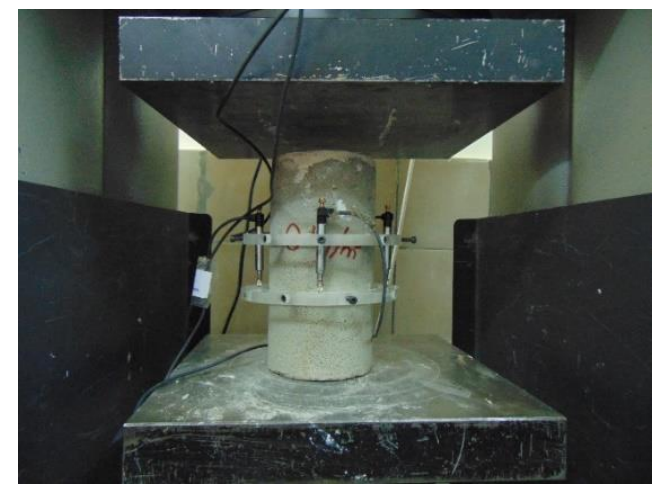

(c) Testing set-up with LVDTs

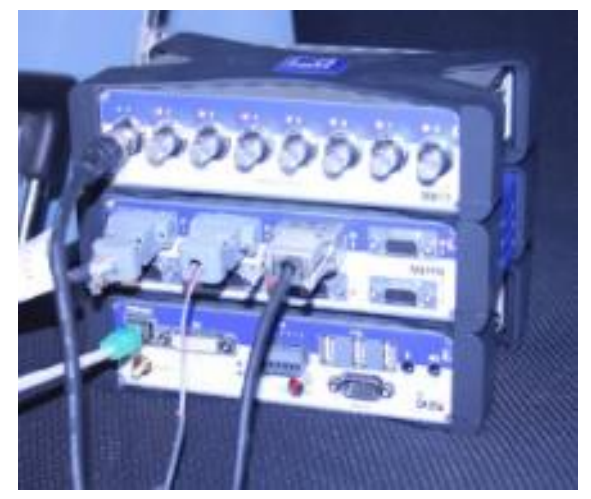

(b) HBM DAQs

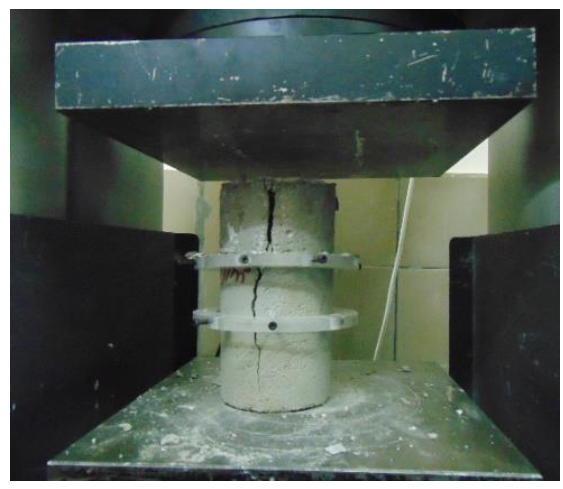

(d) Failed Specimen under Compression

Fig. 4 Testing of CLC cylinder under Compression 


\subsection{Test Methods}

The testing code for fiber reinforced CLC blocks under compression and flexure are not available yet. Standard codes of fiber reinforced concrete such as ASTM C1609/C [44] and JSC SF-4 [45] were used as guidelines to establish load-deflection curve of flexure specimen. ASTM C39 [46] was used for establishing axial compressive behavior of cylindrical specimens. Flexure specimens were tested using servo-controlled hydraulic testing machine and loading was increased at a rate of $0.1 \mathrm{kN} / \mathrm{sec}$ upto $90 \%$ of peak load and then in displacement control loading at $0.001 \mathrm{~mm} / \mathrm{sec}$ to capture the post-peak behaviourbehavior. Flexural specimens were tested in third-point loading. Loads were measured using the load cell of the frame and displacements were measured using liner variable displacement transducers (LVDT) mounted on the specimen. Compressive test specimens were tested in uniaxial compression using rigid steel plates on a servo-controlled compression testing machine using displacement control. Displacement, strain and load was measured through an external Data Acquisition System (DAQ). Test setup for compression and flexure is shown in Fig. 4 and 5 respectively.

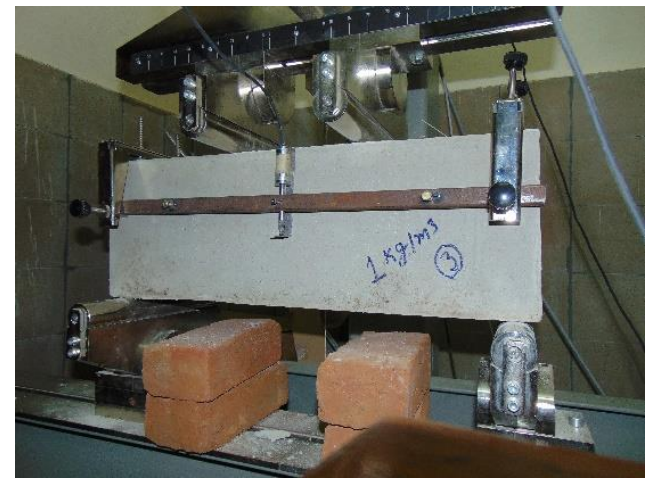

(a) Specimen ready for testing

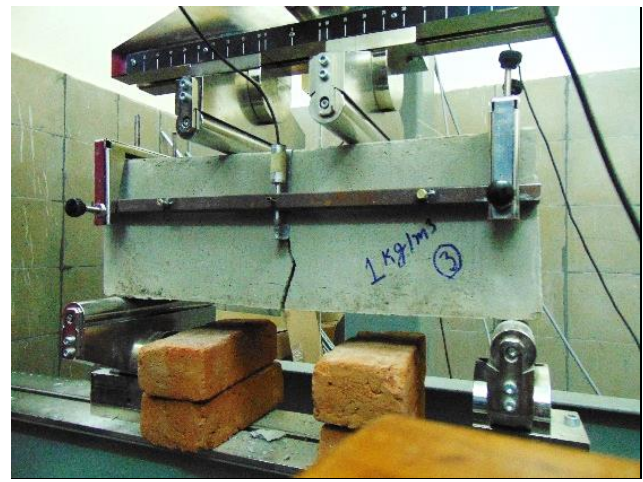

(b) Specimen ready for testing

Fig. 5 Testing of CLC blocks under Flexure 


\subsection{Ductility Measurement}

210 The effectiveness of fiber reinforcement is measured in terms of its energy dissipation 211 capacity. It is also called as toughness index. The following section describes how this index 212 is calculated under compression and flexure.

\subsubsection{Compressive Toughness Index}

215 Compressive toughness index (CTI) is defined as area under the stress-strain curves under compression, which is the energy absorbed prior to complete failure of specimen as shown in

217 Fig. 68 8 . In the present study, linear variable displacement transducers (LVDTs) were mounted on the specimen in the middle third region of cylinders. The limiting strain that can be captured accurately using LVDTs of the test setup used in this study was 0.01 . Therefore, a compressive toughness index upto 0.01 strain was calculated and reported in Table 3.

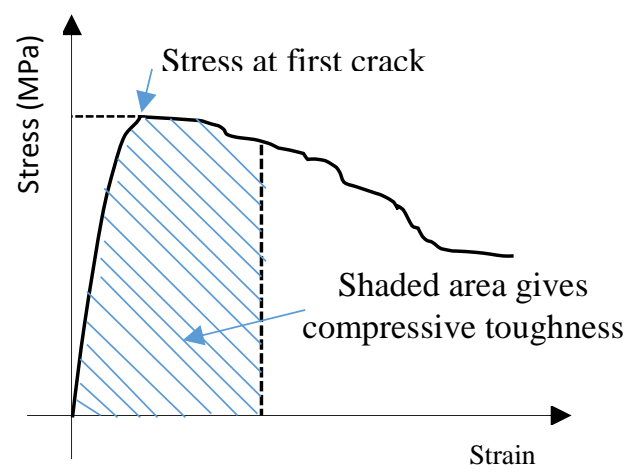

Fig. 6. Typical Stress-strain Graph for fiber- Reinforced Concrete Cylinders under

\subsubsection{Flexural Toughness Equivalent}

Ductility under flexure is commonly measured using the Japanese standard test method JSCE-SF4, which uses beams in a third-point loading arrangement. Load-deflections curves 
are generated as shown in Fig. 7. The Re.3.6 value, measure of the ductility, is the average load applied as the beam deflects to $3.6 \mathrm{~mm}$ expressed as a ratio of the load to first crack. strength as defined by the JSCE-SF4 [45] for a deflection of $l / 150 \mathrm{~mm}$, as denoted as fe,3.6, has been calculated as:

$$
f e, 3.6=\frac{P_{\text {mean }, 150} * l}{b d^{2}}
$$

where $P_{\text {mean. } 150}$ is the area under the load-deflection curve divided by the limit deflection of $\mathrm{mm}, 150 \mathrm{~mm}$ and $150 \mathrm{~mm}$, respectively).

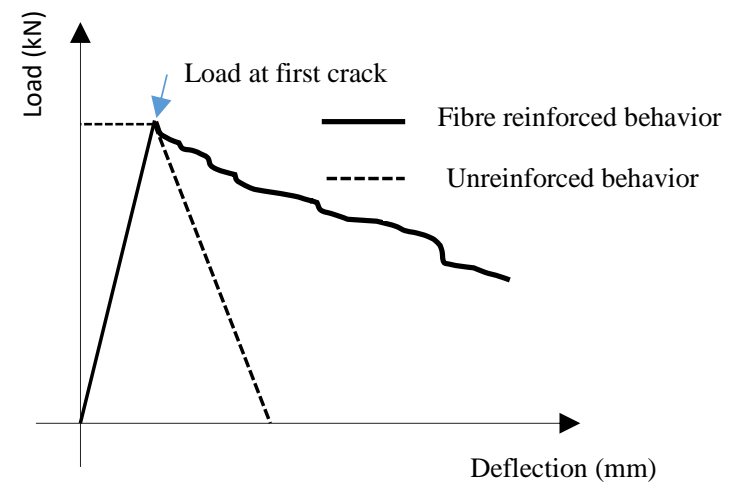

Displacement of $3.6 \mathrm{~mm}$ was used as basis for calculating the equivalent flexural strength ratio as all specimens had undergone a minimum of this displacement. The equivalent flexural strength ratio (Re.3.6) is calculated per the concrete society report TR34-2003 [47]. ASTM C 1609 [44] standards defines the equivalent flexural strength at the deflection of 3.6 $\mathrm{mm}(\mathrm{Re}, 3.6)$ which is expressed as a percentage of the flexural strength of the concrete as shown below, where $f_{c t}$ is the flexural strength calculated from the peak load. $\operatorname{Re}, 3.6=\frac{f_{e, 3.6}}{f_{c t}}$ 


\section{RESULTS AND DISUCUSSIONS}

\subsection{Slump}

249

CLC mix used in the study, flowed into the moulds like self-compacting concrete and

250

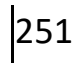
remained unaffected by addition of fibers. It showed equally good mobility into the moulds event after addition of high volume of fiber dosages. This can be attributed to free movement of air voids around the fibers which could have been restricted had there been the coarse aggregate of normal concrete. CLC mix used in this study does not have any aggregates. The mix contained only cement, fly-ash, foaming agent, water and different dosages of fibers. Hence, the mix remained in liquid state even after adding fibers. Patty tests showed the spread was more than $500 \mathrm{~mm}$ even at addition of higher fiber dosages of $0.55 \%$. Besides, the addition of fibers was found to enhance the roughness on the surfaces of blocks and would help in ensuring a proper bond between the blocks and mortar from masonry construction point of view. Improved workability tests like slump flow test and flowability test are scope for further work.

\subsection{Behavior under Compression}

Toughness Index is the measure of energy absorbed by the material in undergoing a specified amount of strain, being the area under the Stress-strain graph as shown in Figs. $\underline{8} 10$, 911. A limiting strain of 0.01 was used for calculation of strain energy. Three series of specimen were tested. Series 1 had control specimen with no fiber. Series 2 had specimen with only macro fibers. Series 3 had macro fibers with a constant micro fiber dosage of 0.02\%. Unreinforced CLC exhibited brittleness with the post-peak strength decreasing rapidly with increase in strains after the peak stress. However, for the fiber reinforced specimens, the post-peak strength degradation was more gradual indicating the addition of fibers have enhanced the toughness as shown by increase in the strain energy in Table 3. 
Table 3. Test Results of CLC cylinders in Compression with and without Fibers

\begin{tabular}{|c|c|c|c|c|c|c|c|c|c|}
\hline \multirow[b]{2}{*}{ Series } & \multirow[b]{2}{*}{ Specimen } & \multicolumn{5}{|c|}{ Peak Compressive Strength (MPa) } & \multirow{2}{*}{$\begin{array}{c}\text { Mean } \\
\text { Comp } \\
\text { Strength } \\
(\mathrm{MPa})\end{array}$} & \multirow[b]{2}{*}{$\begin{array}{l}\text { Std } \\
\text { Dev }\end{array}$} & \multirow[b]{2}{*}{$\begin{array}{r}\text { CTI } \\
\left(10^{-3}\right)\end{array}$} \\
\hline & & 1 & 2 & 3 & 4 & 5 & & & \\
\hline I & Control & 4.00 & 4.04 & 3.83 & 4.18 & 3.41 & 3.89 & 0.30 & 6.99 \\
\hline \multirow{4}{*}{$\begin{array}{c}\text { II } \\
\text { (only } \\
\text { macro) }\end{array}$} & ma-0.22-mi-0.0 & 6.19 & 4.82 & 7.21 & 6.18 & 5.28 & 5.94 & 0.92 & 47.20 \\
\hline & ma-0.33-mi-0.0 & 6.52 & 5.41 & 7.67 & 5.24 & 5.95 & 6.16 & 0.98 & 54.90 \\
\hline & ma-0.44-mi-0.0 & 6.04 & 7.35 & 6.21 & 6.55 & 6.78 & 6.58 & 0.52 & 66.00 \\
\hline & ma-0.55-mi-0.0 & 7.11 & 5.31 & 6.42 & 6.71 & 6.9 & 6.49 & 0.71 & 63.50 \\
\hline \multirow{4}{*}{$\begin{array}{c}\text { III } \\
\text { (hybrid) }\end{array}$} & ma-0.11-mi-0.02 & 3.95 & 3.86 & 3.93 & - & - & 3.91 & 0.15 & 57.55 \\
\hline & ma-0.22-mi-0.02 & 5.98 & 6.43 & 7.62 & - & - & 6.67 & 0.84 & 68.27 \\
\hline & ma-0.33-mi-0.02 & 7.35 & 8.96 & 8.86 & - & - & 8.39 & 0.90 & 72.13 \\
\hline & ma-0.44-mi-0.02 & 7.30 & 8.02 & 10.0 & - & - & 8.44 & 1.40 & 78.46 \\
\hline
\end{tabular}

CTI $^{*}$-Compressive Toughness Index

\subsection{Stress-Strain Behavior}

Stress-stain curve under compression for the unreinforced specimen showed a linear

behavior upto $30 \%$ the peak load (Fig. 8). Thereafter, non-linear behavior was observed upto the peak stress. After the peak load, the failure was quite sudden as the specimen collapsed showing little resistance to the applied strain. For cylinders with the structural fibers, the behavior until the peak load was similar to that of unreinforced specimen but with a marginal increase in the initial modulus of elasticity (Fig. 8). The increase in modulus of elasticity can be attributed to higher modulus of elasticity of fibers (about 10,000 MPa) compared to that of CLC (about $3000 \mathrm{MPa}$ ). The peak strength increased with the increase in fiber dosage. The post-peak region of fiber reinforced specimen showed a very ductile behavior. The area under the stress-strain curve increased with increase in fiber dosage. The stress in the post-peak remained almost close to that of peak compressive load. Hybrid-fiber reinforcement on the 
other hand also showed appreciable increase in modulus of elasticity upto the peak load, while the strength degraded in the post-peak region without much degradation in modulus of elasticity (Fig. 9). The stress-strain curves for specimens with only macro fibers and hybrid fibers are compared in Fig. 10. Peak compressive strength in hybrid specimen increased compared to that of cylinders with only macro-fibers. This can be explained by the better arresting of cracks at micro-scale by micro-fiber and synergetic role of both fibers which led to the increase in peak compressive strength and better post-peak behavior. It is worth mentioning that clay bricks of low strength (varying from 4 to $10 \mathrm{MPa}$ ) are commonly used for masonry load bearing and infill wall construction in the developing countries. Compressive strength of 4 to $8 \mathrm{MPa}$ was achieved in CLC through addition of fibers in compression. Therefore, the fiber reinforced CLC can potentially replace the existing clay bricks with superior mechanical properties. Cost optimization of the developed fiber reinforced CLC can be a scope for future work.

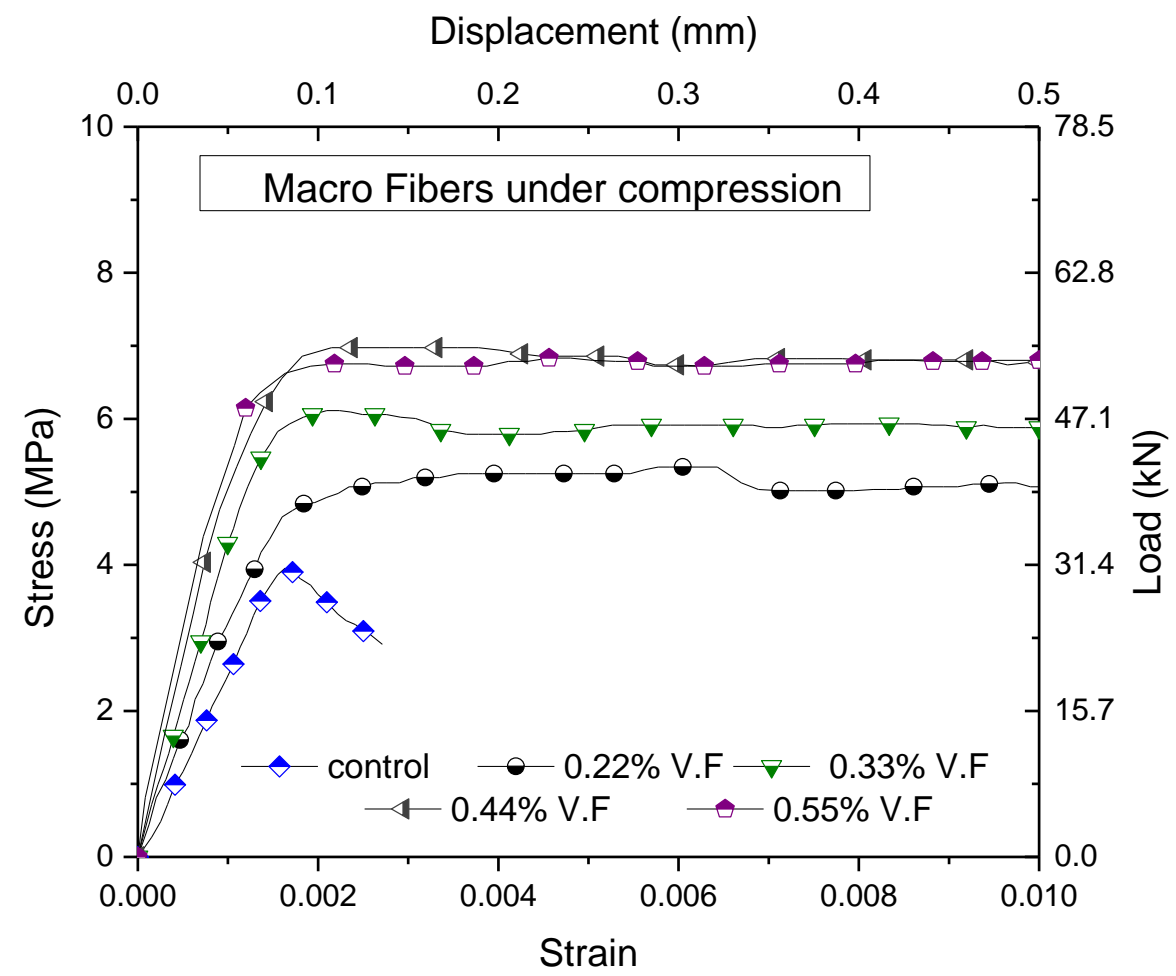

Fig. 8. Behavior under axial compression of CLC cylinders without Macro-fiber dosage 


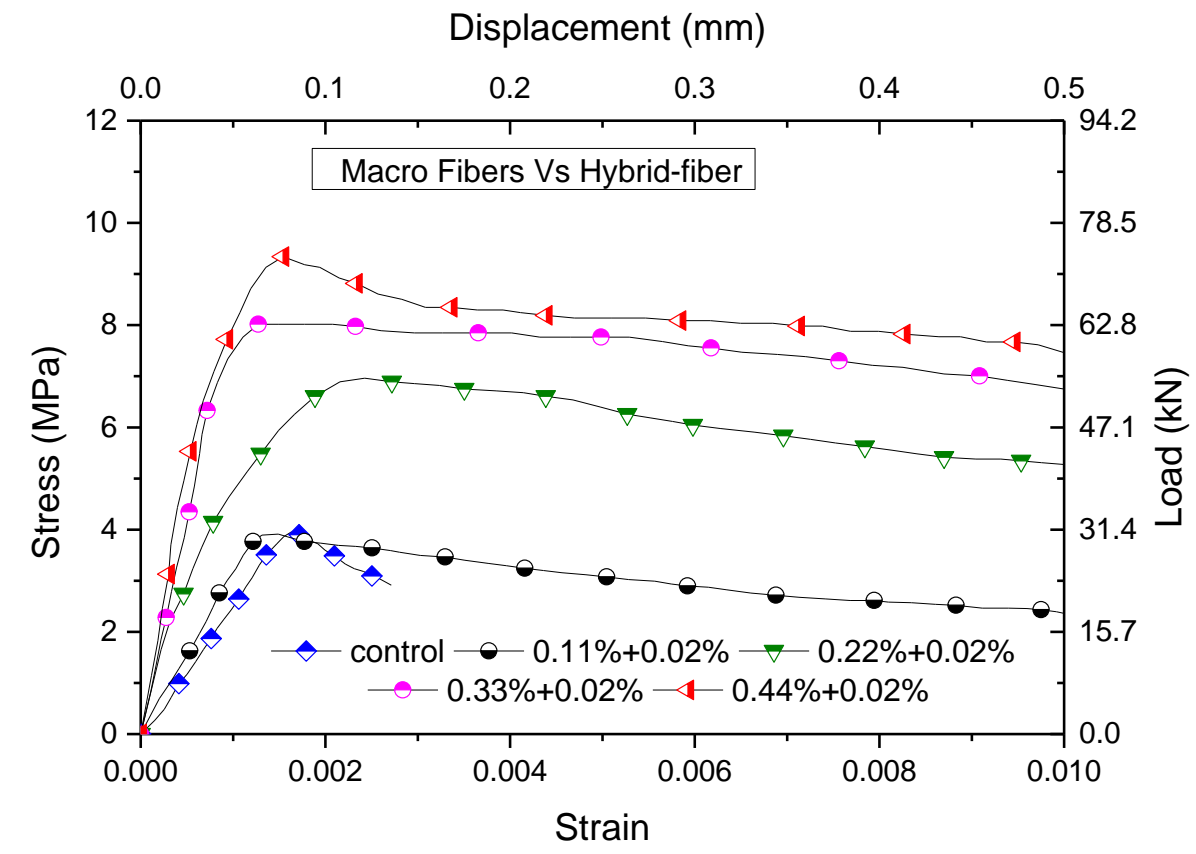

Fig. 9. Behavior under axial compression of CLC cylinders with Hybrid Fiber dosage

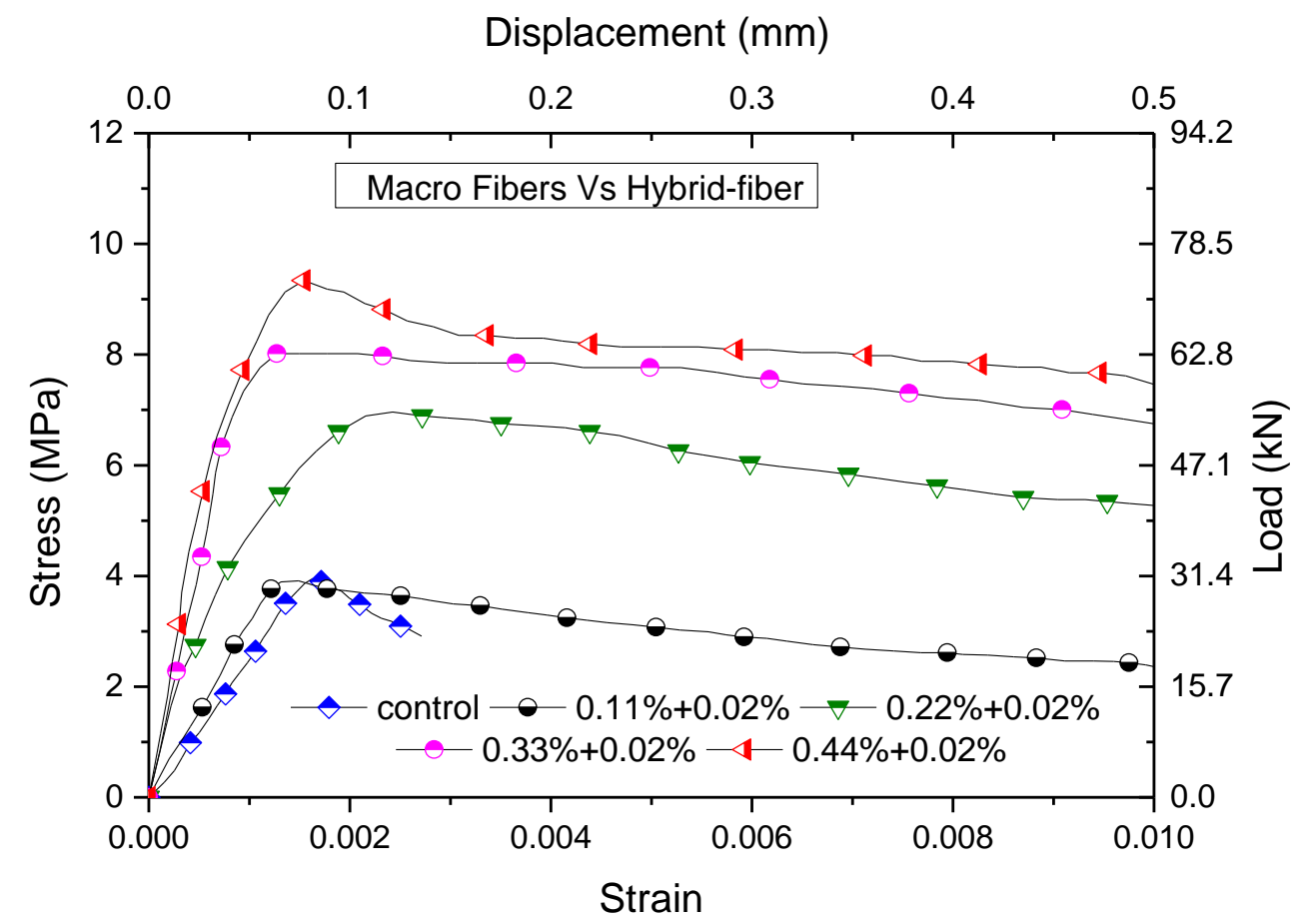

307

Fig. 10. Comparison of Macro with Hybrid fiber dosage performance in compression 


\subsection{Flexural Stiffness and Peak Strength}

311 Figs. 113-137 show the load-displacement response of CLC blocks with different fiber dosages under flexure. Table 4 shows the peak flexural load and the statistical values calculated for five samples tested at different dosage of fiber reinforcement. Peak flexural 314 strength of CLC increased with increase in fiber dosage (Table 4). Figs. 11-13, 12 shows the close up view of load-displacement curve upto $0.5 \mathrm{~mm}$ displacement. Increase in ductility can be observed from better post-peak behavior due to addition of fibers. Re,3.6 factor from JSC SF-4 [45] was calculated and reported in Table 4 for the quantitative measurement of ductility.

\subsection{Load-Displacement Behavior}

Load displacement curve for the unreinforced specimen showed a linear behavior until the peak load. Thereafter, the softening behavior was quite sudden as the specimen collapsed showing little resistance to the applied displacement. The identical pre-peak and immediate post-peak softening responses from control and fiber reinforced beams indicate that the stress transfer to fibers takes place after the formation of the crack. In a composite material, discontinuous random fibers will have different embedment lengths with respect to crack plane. The crack opening is accommodated within fiber slip and elongation. The resistance to crack opening provided by fibers with increasing slip is controlled by debonding and sliding of fibers from the cementitious matrix.

The peak load increased with increase in fiber dosage (Figs. 11,12). For heavily macroreinforced specimens (more than $0.44 \%$ ), the regain in strength after the first cracking was quite significant. For low volume fraction (less than $0.22 \%$ ), there are a small number of 
fibers bridging the crack that sustain the load. The capacity provided by the number of fibers crossing the crack is significantly less than the first crack load and load carrying capacity decreases rapidly with increasing deformation. For intermediate volume fraction (between $0.22 \%$ to $0.44 \%$ ), after the drop in load associated with the formation of a crack, the load carrying capacity provided by the fibers produces a progressive yet gradual decrease in the load carrying capacity. For high volume fraction, after first crack, there are a large number of fibers bridging the crack and the resistance to crack opening provided by the fibers is larger than the first crack load. As the load increases, more cracks form along the length of specimen. Specimen with low dosage of fiber has shown lesser regain in strength in the postpeak region. Hybrid-fiber reinforcement on the other hand showed an appreciable increase in stiffness upto the peak load, also the area under load-displacement is increased when compared to that of macro-fiber reinforced specimen (Fig. 13).

Table 4. Peak Flexural Capacity $\left(\mathrm{f}_{\mathrm{ct}}\right)$ and Re,3.6 Values.

\begin{tabular}{|c|c|c|c|c|c|c|}
\hline Series & Specimen & $\begin{array}{l}\text { Std. } \\
\text { Dev } \\
(\mathrm{kN})\end{array}$ & $\begin{array}{c}\mathrm{f}_{\mathrm{ct}} \\
(\mathrm{kN})\end{array}$ & $\begin{array}{l}\text { Increase in } \mathrm{f}_{\mathrm{ct}} \\
\text { due to } \\
\text { addition of } \\
\text { fibers }(\%)\end{array}$ & Re,3.6 value & $\begin{array}{c}\% \text { increase in } \\
\text { Re, } 3.6\end{array}$ \\
\hline $\mathrm{I}$ & Control & 0.680 & 6.297 & - & 0.0445 & - \\
\hline \multirow{4}{*}{$\begin{array}{c}\text { II } \\
\text { (Only } \\
\text { Macro) }\end{array}$} & ma-0.22-mi-0.0 & 0.884 & 7.034 & 11.7 & 0.5492 & 11.34 \\
\hline & ma-0.33-mi-0.0 & 0.483 & 8.191 & 30.1 & 0.6514 & 13.64 \\
\hline & ma-0.44-mi-0.0 & 0.905 & 9.236 & 46.7 & 0.6729 & 14.12 \\
\hline & ma-0.55-mi-0.0 & 0.977 & 10.031 & 59.3 & 0.8014 & 17.00 \\
\hline \multirow{4}{*}{$\begin{array}{c}\text { III } \\
\text { (Hybrid) }\end{array}$} & ma-0.11-mi-.02 & 0.873 & 7.988 & 14.6 & 0.3847 & 7.65 \\
\hline & ma-0.22-mi-.02 & 0.530 & 8.594 & 36.6 & 0.5563 & 11.51 \\
\hline & ma-0.33-mi-.02 & 1.158 & 9.436 & 49.8 & 0.6637 & 13.91 \\
\hline & ma-0.44-mi-.02 & 1.865 & 10.678 & 69.6 & 0.7259 & 15.31 \\
\hline
\end{tabular}




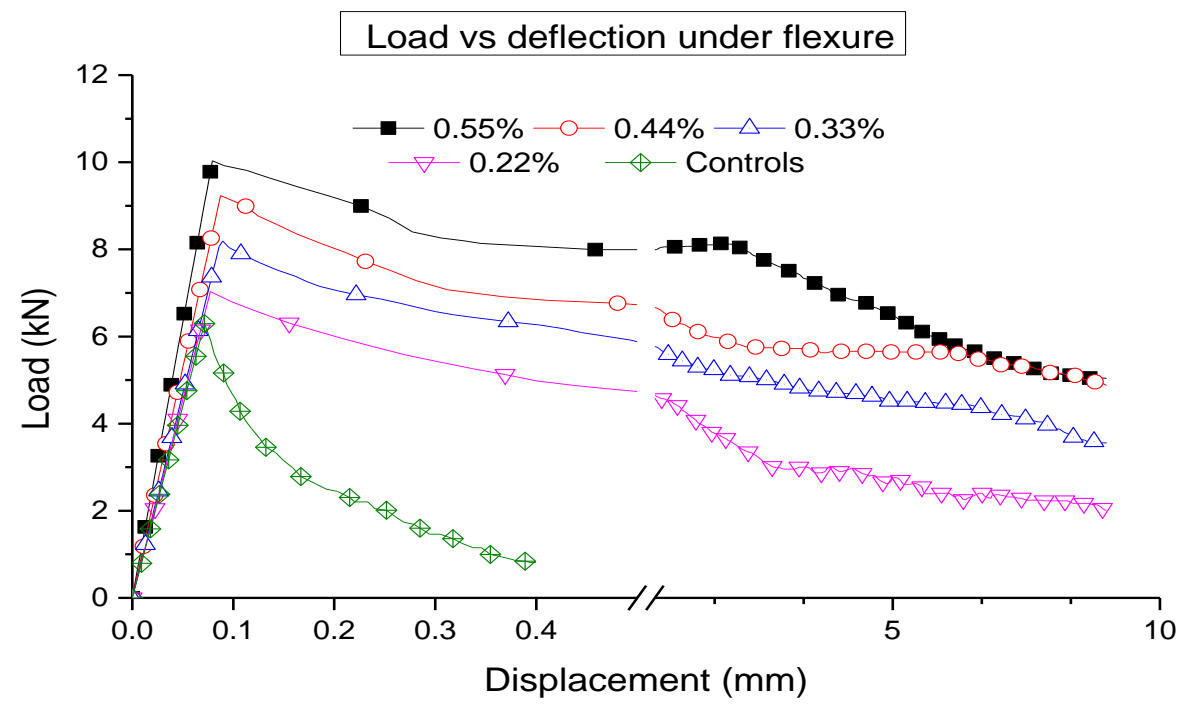

Fig. 11. Behavior of CLC blocks without microfiber dosage in flexure

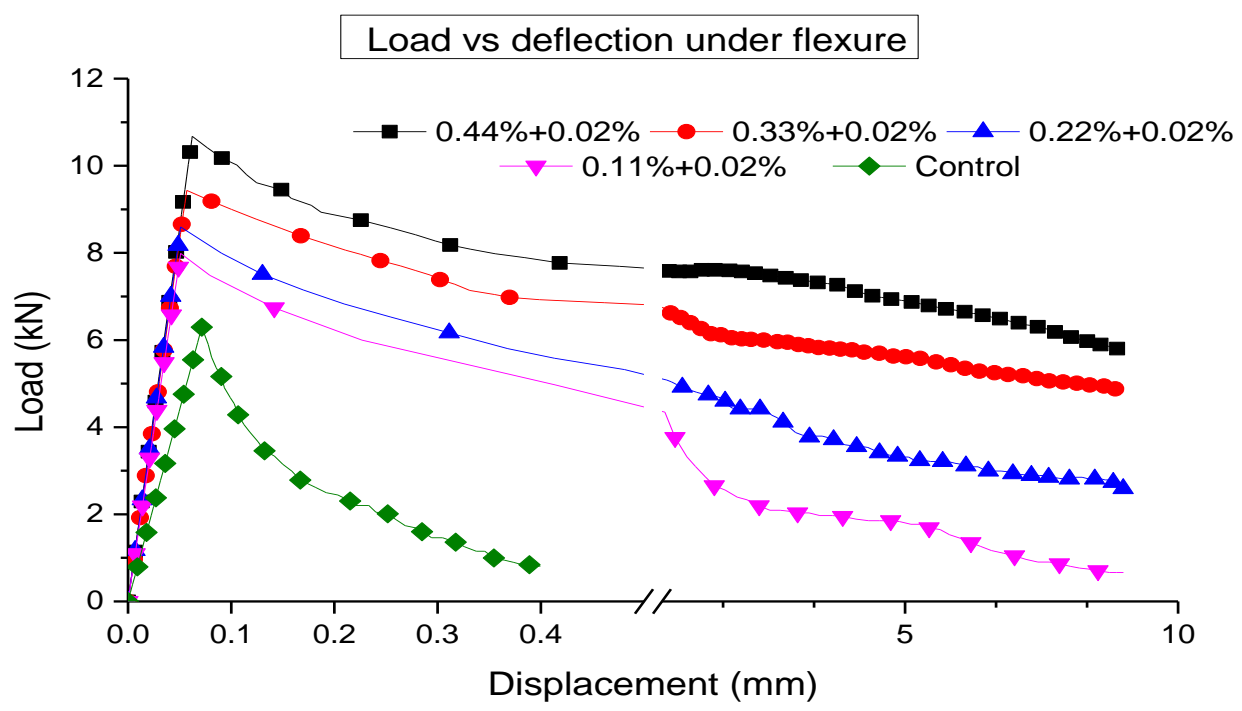

Fig. 12. Behavior of CLC blocks with microfiber dosage in flexure 


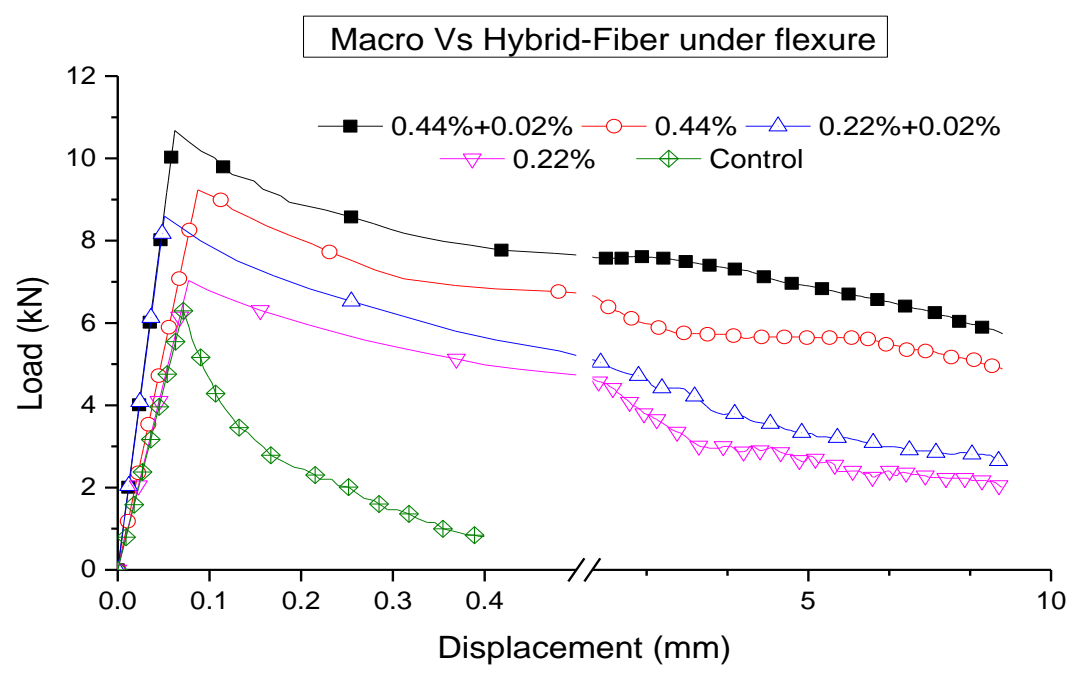

354

Fig. 13. Comparison of Macro and Hybrid Fiber Dosage Performance in Flexure

\section{FAILURE MODES}

\subsection{Compressive Testing}

The failure pattern followed by unreinforced specimen is predominantly a single explicit of micro cracks at the failure as shown in Fig. 14b,c.

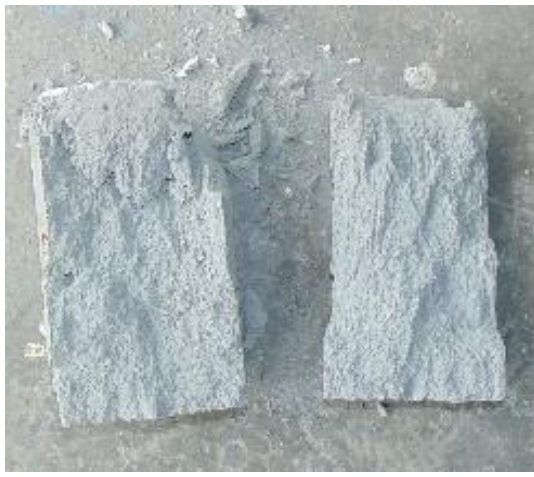

(a) Control specimen

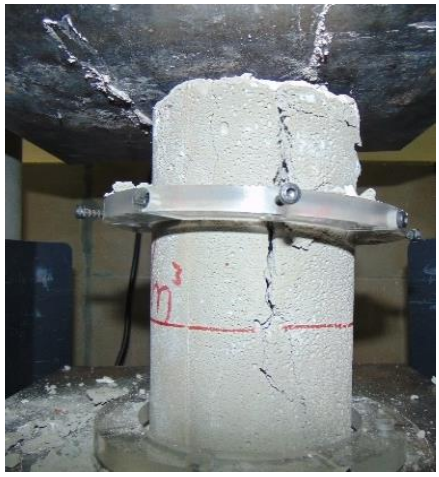

(b)Macro-fiber reinforced specimen

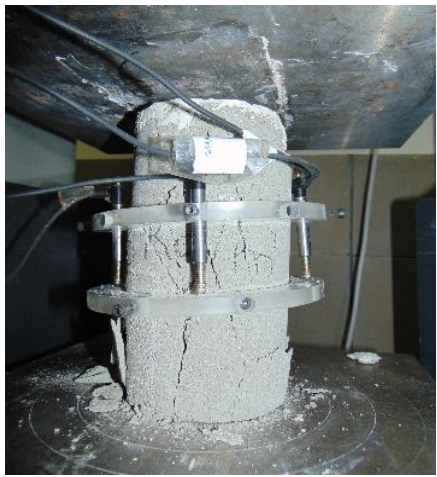

(c) Macro and fibrillated reinforced

Fig. 14. Failure of blocks under compression with and without fibers 
The failure pattern followed by unreinforced specimen is predominantly a single explicit crack as shown in Fig. 15a. On the other hand, the FRCLC blocks showed post-peak

367

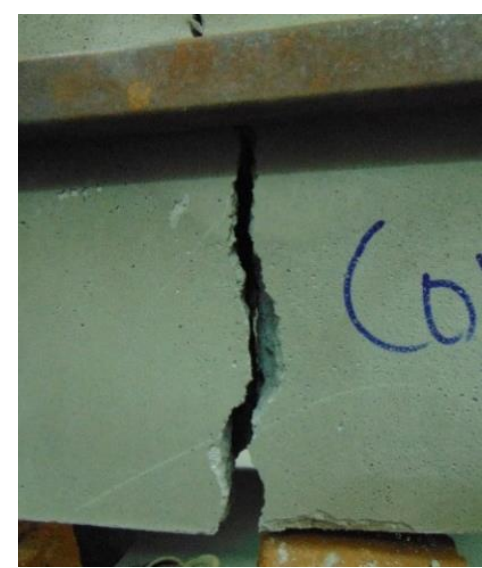

(a)Control specimen

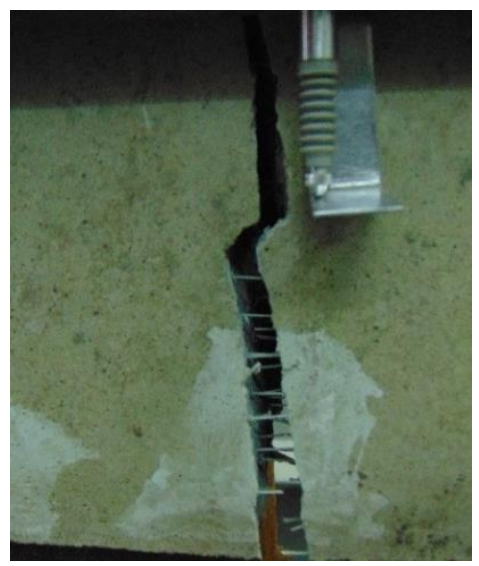

(b)Macro-fiber reinforced specimen

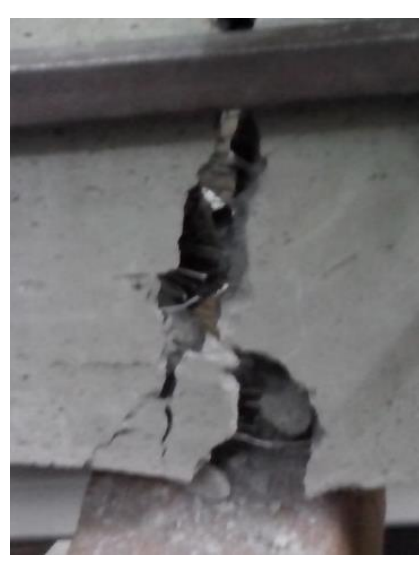

(c) Macro and fibrillated reinforced

Fig. 15 Failure of blocks under flexure with and without fibers

\section{SCOPE FOR FUTURE WORK}

374 The present study showed that CLC blocks with good compressive, tensile and flexural strength can be developed that can be a potential alternative of the existing AAC blocks. Future research should focus on understanding the effect of hybrid fiber reinforcement on cellular light weight masonry prisms under compression and flexure. Reducing water absorption capacity of the developed CLC and the effect of fiber addition has to be studied. The fiber volume at a particular point becomes excessive and gives little improvement in the 
strength of material while significantly lowering the workability. Equation proposed by Martini et al. [48] for maximum content of fiber $\left(\phi_{f}\right)_{\max }$ in mix is given by:

$$
\left(\phi_{f}\right)_{\max }=\frac{400}{r}\left(1-\frac{\phi_{s}}{\phi_{m}}\right) \quad(\text { in } \%)
$$

where ' $\phi_{s}$ ' denotes the packing fraction of sand in the mixture, ' $\phi_{m}$ ' is the dense packing fraction of the sand and ' $r$ ' is aspect ratio of fiber. The current study does not make use sand in the mix proportions, following which the equation cannot be directly used here. However modifying the above equation to suit for mixes without sand can be the scope of future work.

\section{CONCLUSIONS}

Development of fiber reinforced CLC for masonry applications was explored through addition of macro-fiber reinforcement and hybrid-fiber reinforcement. The effect of synthetic fiber reinforcement on the mechanical behavior of CLC was studied by testing cylinders under compression and blocks under flexure. Based on the parameters investigated in this study, the following major conclusions can be drawn.

- Compressive strength increased progressively with addition of macro fiber dosage. It increased upto $52.6 \%$ for $0.22 \%$ and upto $66.8 \%$ for $0.55 \%$ volume fraction when compared to that of control specimen. Increase in strength is not proportional to increase in fiber dosage. There was minimal change in strength and post-peak behavior between $0.44 \%$ and $0.55 \%$ and this indicated there exists an optimum dosage beyond which there will not be much improvement in the performance.

- The compressive toughness index increased by a factor of 6.7 for $0.22 \%, 7.7$ for $0.33 \%, 9.4$ for $0.44 \%$ and 9.0 for $0.55 \%$ volume fraction addition of macro fiber.

- Due to addition of macro-fibers, the flexural strength increased upto $11.7 \%$ for $0.22 \%$ 


\section{References}

[1] Narayanan N , Ramamurthy K. Structure and properties of aerated concrete: a review. Cem Conc Comp. 2000; 22:621-329

[2] Vine-Lott K. Production of foam concrete by microcumpter. The Concrete Society. 1985; 19:1214

[3] Satheeshbabu S. Life cycle assessment of cellular lightweight concrete block-a green building material. Journal of Environmental Technology and Management. 2010; 1554:69-79

[4] Hassan KE , Cabrera JG, Bajracharya YM. The Influence of Fly Ash Content and Curing Temperature on the Properties of High Performance Concrete. In: International Conference on 
Deterioration and Repair of Reinforced Concrete in the Arabian Gulf; 1997; Bahrain. p. 311-319.

[5] Stuart KD , Anderson DA, Cady PD. Compressive Strength Studies on Portland Cement Mortars containing Fly Ash and Superplasticizers. Cem Conc Res. 1988; 10:829-832

[6] Kearsley EP , Wainwright PJ. Ash Content for Optimum Strength of Foamed Concrete. Cem Conc Res. 2002; 32:241-246

[7] Krishna BSK. Cellular Light-Weight Concrete Blocks as a Replacement of Burnt Clay Bricks. International Journal of Engineering and Advanced Technology. ; 2: 2249-8959

[8] Cellular Concrete for Thermal Insulation. Delhi: Bureau of Indian Standards; 1972. IS:6598.

[9] Bentur A , Mindess S. Fiber Reinforced Cementitious Composited. 2nd ed.: Taylor and Francis; 2007.

[10] Hsie M , Tu C , Song PS. Mehanical properties of polypropylene hybrid fiber-reinforced concrete. Material Science and Engineering. 2008; A-494:153-157

[11] Albert ML , Elwi AE , Cheng JR. Strengthening of unreinforced masonry walls using FRPs. J Comp Construct 2001; 2:76-84

[12] Evaluation of earthquake damaged concrete and masonry wall buildings. basic procedures manual. California: Applied Technology Council, Federal Emergency Management Agency (FEMA); 1999. Report No.: ATC-43,FEMA 306.

[13] Rudolph, Valore RC. Cellular concrete part 2 physical properties. ACI J 1954;50:817-36.

[14] Sengupta J. Development and application of light weight aerated concrete blocks from fly ash. Indian Concr J 1992; 66:376-390

[15] Panesar DK. Cellular concrete properties and the effect of synthetic and protein faoming agents. Constr and Build Mater, 2013, 44: 575-584.

[16] Esmaily H, Nuranian, H. Non-autoclaved high strength cellular concrete from alkali activated slag. Constr and Build Mater, 2012, 26: 200-206.

[17] Yang KH, Lee, KH. Tests on high-performance aearated concrete with a lower density. Constr and Build Mater, 2015, 74: 109-117.

[18] Laurent JP , Guerre-Chaley C. Influence of water content and temperature on the thermal conductivity of autoclaved aerated concrete. Mater Struct. 1995; 28:164-72

[19] Leitch FN. The properties of aerated concrete in service. In:Proceedings of the Second International Conference on Lightweight Concretes. London, 1980. 
[20] Mobasher B , Li CY. Mechanical properties of hybrid cement based composites. ACI Mater J 1996; 93:284-299

[21] Perez-Pena M , Mobasher B. Mechanical properties of fiber reinforced lightweight concrete composites. Cem Conc Res. 1994; 24:1121-1132

[22] Qian CX , Stroeven P. Development of hybrid polypropylene-steel fibre-reinforced concrete. Cem. Concr. Res. 2000; 31:63-69

[23] Ronald F , Carol DH. Engineering Material Properties of a Fiber Reinforced Cellular Concrete. ACI J. 1998; 95-M61:631-635

[24] Deng Z, Li J. Mechanical Behaviors of Concrete Combined with Steel and Synthetic MacroFibers, International Journal of Physical Sciences Vol. 1 (2), pp. 057-066, October,2006.

[25] Lukaitis A, Keriene J, Mikulskis D, Sinica M, Sezemanas G. Infleuence of fibrous additives on properties of aearated autoclaved concrete forming mixtures and strength characteristics of products. Constr and Build Mater, 2009, 23: 3034-3042.

[26] Brugg Conctec AG. Concrix-Technical Datasheet. [Online]. Available from: HYPERLINK http://www.bruggcontec.com/English/Home/Concrix/tabid/474/language/en-US/Default.aspx .

[27] Hoff GC. Porosity-strength considerations for cellular concrete. Cem Concr Res.1972; 2:187-195

[28] Mitsuda T , Chan CF. Anomalous tobermorite in autoclaved aerated concrete. Cem Concr Res. $1977 ; 7: 187-195$

[29] Alexanderson J. Relations between structure and mechanical properties of autoclaved aerated concrete. Cem Concr Res. 1979; 9:493-521

[30] Watson KL. Autoclaved aerated concrete from slate waste, Part 2-Some property/porosity relationships. Int J Lightweight Concr. 1980; 3:121-3

[31] Tada S , Nakano S. Microstructural approach to properties of moist cellular concrete. In Proceedings Autoclaved Aerated Concrete, Moisture and Properties; 1983; Amsterdam. p. 71-89.

[32] Tam CT , Lim TY, Lee SL. Relationship between strength and volumetric composition of moistcured cellular concrete. Mag Concr Res. 1987; 39:12-8

[33] Georgiades A, Ftikos CH. Effect of micropore structure on autoclaved aerated concrete shrinkage. Cem Concr Res. 1991; 21:655-62

[34] Odler I, Robler M. Investigations on the relationship between porosity, structure and strength of hydrated portland cement pastes: Effect of pore structure and degree of hydration. Cem Concr 
Res. 1995; 15:401-10

[35] Hanecka C, Koronthalyova O, Matiasovsky P. The carbonation of autoclaved aerated concrete. Cem Concr Res. 1997; 27:589-99

[36] Durack JM , Weiqing L. The properties of foamed air cured fly ash based concrete for masonry production. In: Proceedings of the Fifth Australasian Masonry Conference; 1998; Gladstone, The Queensland, Australia. p. 91-68.

[37] Kearsley EP , Wainwright PJ. The effect of porosity on the strength of foamed concrete. Cem Concr Res. 2002; 32:233-239

[38] Jones MR, McCarthy A. Preliminary views on the potential of foamed concrete as a structural material. Mag Concr Res 2005;57:21-31

[39] Ramamurthy K , Nambiar EK. A classification of studies on foam concrete. Cem Concr Comp. 2009; 31:388-396

[40] Ameer AH , Nicholas HT , Andrew RD. Microstructural approach to properties of moist cellular concrete. Cem Conc Comp. 2015; 75:227

[41] ASTM. Standard specification for foaming agents used in making preformed foam for cellular concrete. ; 1992. ASTM C 869-91.

[42] Jitchaiyaphum K, Sinsiri T, Chindaprasirt P. Cellular lightweight concrete containing pozzolan materials. In: The Twelfth East Asia-Pacific Conference on Structural Engineering and Construction; 2011; Thailand. p. 1157-1164.

[43] Plain and Reinforced Concrete-Code of Practice (Fourth Revision). New Delhi, India.: Bureau of Indian Standards; 2000. IS: 456.

[44] ASTM. Standard Test Method for Flexural Performance of Fiber-Reinforced Concrete (Using Beam With Third-Point Loading). Annual Book ASTM Standards. ; 2007. ASTM C 1609/C $1609 \mathrm{M}-07$.

[45] Method of Test for Flexural Strength and Flexural Toughness of Steel Fiber Reinforced Concrete. Concrete Library; 1984. JSCE-SF4.

[46] ASTM. Standard Test Method for Compressiv1e Strength of Cylindrical Concrete Specimens. Annual Book ASTM Standards. ; 2004. Report No.: ASTM C 39/C39M-04a.

[47] Concrete Industrial Ground Floors: a Guide to Design and Construction. Concrete Society UK. Report No.: TR34. 
[48] Martinie L, Rossi P, Roussel N. Rheology of fiber reinforced cementitious materials: classification and prediction Cem Concr Res 2010;40:226-234 